\title{
Is the Emergence of Dothistroma Needle Blight of Pine in France Caused by the Cryptic Species Dothistroma pini?
}

\author{
B. Fabre, R. Ioos, D. Piou, and B. Marçais
}

First and fourth authors: INRA Nancy, UMR INRA/UHP 1136 Interactions Arbres/Microorganismes, 54280 Champenoux, France; second author: ANSES, Laboratoire de la Santé des végétaux, Domaine de Pixérécourt, BP90059, F-54220 Malzéville, France; and third author: Ministère de l'agriculture de l'alimentation et de la pêche, DGAL-SDQPV, Département de la Santé des Forêts, 252 rue de Vaugirard, 75732, cedex 15, Paris.

Accepted for publication 12 July 2011.

\begin{abstract}
Fabre, B., Ioos, R., Piou, D., and Marçais, B. 2012. Is the emergence of Dothistroma needle blight of pine in France caused by the cryptic species Dothistroma pini? Phytopathology 102:47-54.

Dothistroma needle blight (DNB) emerged in France in the past 15 years. This disease is induced by two closely related species: Dothistroma septosporum and D. pini. Although both species are currently present in France, only D. septosporum was reported in the past. We investigated whether a recent arrival of $D$. pini in France could be a cause of the DNB emergence. We analyzed herbarium specimens of pine needles with DNB

bution within the country of $D$. septosporum and $D$. pini and compared it with the spatial pattern of DNB reported in the Département de la Santé des Forêts (DSF; French forest health monitoring agency) database. Although D. pini was detected on herbarium specimens from 1907 and 1965, it was not frequent in France in the past. Today, it is frequent, although not present throughout the country, being absent from the north and the east. There is no relationship between the D. pini distribution in France and the spatial pattern of DNB reported in the DSF database. Thus, the emergence of DNB in France cannot be explained by a recent arrival of D. pini.
\end{abstract} symptoms using polymerase chain reaction techniques to study the past frequency of $D$. pini in France. We also determined the present distri-
Additional keywords: Mycosphaerella pini, Pinus.
The emergence of plant diseases is an important concern throughout the world $(1,14)$. Emergence can be defined by the increase in problems caused by a disease, whether the disease increases its range or its severity within the same range. The most important factors reported to influence disease emergence are climate change and the introduction of pathogens in new areas by trade $(1,9)$. Assessing the relative importance of those two factors is a major scientific issue in epidemiology. Determining whether an emerging disease is caused by an invasive pathogen is not always easy. Indeed, many plant diseases are caused by a complex of cryptic species. This is the case, for example, for many forest tree diseases such as Sphaeropsis shoot blight (10), Dothistroma needle blight (DNB) (4), or oak powdery mildew (21). When a disease caused by a complex of cryptic species emerges, it is often difficult to determine whether the pathogen responsible for the increase in disease severity or range has invaded the area, because knowledge about the past situation is often lacking. For example, it has been shown that oak powdery mildew is caused by several Erysiphe spp. although it was previously thought to be caused only by Erysiphe alphitoides (21). A new, previously unreported species, E. quercicola, was shown to be frequent in the French oak forest (22). However, it is not known how long this species has been present in Europe. It might have been present for a long time, remaining undetected due to inadequate means to distinguish the species.

The use of herbarium specimens is a good means to study the past geographic distribution of plant pathogens. Indeed, detection

Corresponding author: B. Marçais; E-mail address: marcais@ nancy.inra.fr

http://dx.doi.org/10.1094/PHYTO-02-11-0036

This article is in the public domain and not copyrightable. It may be freely reprinted with customary crediting of the source. The American Phytopathological Society, 2012. of Silene anther-smut disease in a herbarium enabled Antonovic et al. (2) to document retrospectively the invasion of North America by Microbotryum violaceum. The development of molecular tools for species identification and quantification greatly improved the prospects of using herbarium specimens. For example, Shaw et al. (25) was able to study the relative frequency of two wheat pathogens, Phaeosphaeria nodorum and Mycosphaerella graminicola, in a 160-year-long experiment. They showed that $\mathrm{SO}_{2}$ pollution was the major factor that controls the relative frequency of the two pathogens, with high $\mathrm{SO}_{2}$ pollution levels strongly favoring $P$. nodorum while low levels favored $M$. graminicola. Herbarium specimens were also used to determine whether the ash pathogen Chalara fraxinea is a recent invader in Switzerland (24).

DNB has strongly affected Laricio pine stands in France in the last 15 years (3). Although the causal pathogen, Dothistroma septosporum, had been present in France since at least the 1960s, it was reported then as only a minor pathogen of pine (18). The disease has emerged also in other European countries and in British Colombia in the recent years $(29,30)$. The emergence of DNB in those areas has been related to recent climate evolution, with an increase in the frequency of favorable warm and wet periods (31). In recent years, it was shown that DNB can be caused by two closely related species with overlapping morphological features (4). D. septosporum (teleomorph: Mycosphaerella pini) is the most important species throughout the world whereas D. pini (teleomorph unknown) was initially reported only in North-America. All isolates from present and past collections of Europe that were investigated using molecular tools were assigned to D. septosporum (4). However, D. pini was recently found in Ukraine and southwestern Russia, where it has been associated with the emergence of DNB on Pinus pallasiana (5), and it was also recently shown that $D$. pini was present in France and Hungary $(6,15)$. It is still not known whether this species has recently arrived in Western Europe, how frequently it is found in 
the pine forest, and whether its arrival might have driven the emergence of DNB.

The aim of this work was to investigate whether the emergence of DNB in France could be linked to a recent introduction of $D$. pini in the country. For that purpose, a collection of Pinus needle herbarium samples was analyzed to determine whether $D$. pini was frequent in France in the past. If a recent arrival of $D$. pini played a significant role in the DNB emergence, the disease severity should be related to the frequency of $D$. pini in the area. Thus, we compared the pattern of DNB severity within the country with the respective geographic distribution of the two Dothistroma spp., taking advantage of the availability of data from the Département de la Santé des Forêts (DSF; French forest health survey system) on DNB occurrence in France in the last 20 years. A second aim of this study was to compare the response to climate of the two Dothistroma spp.

\section{MATERIALS AND METHODS}

Dothistroma spp. distribution in France. A survey of the distribution of D. septosporum and D. pini was organized throughout France. Two different sets of sampling were done. A first set of samples (sample set 1) was collected in stands where a significant DNB impact was reported during the years 2007 to 2010 by the observers of the DSF. For $\approx 20 \%$ of the records, samples were collected and sent to the Laboratoire National de la Protection des Végétaux (LNPV) to confirm the presence of Dothistroma spp. Samples came from 80 different stands. A second set of 136 samples (sample set 2) was collected based on a network of plots established over France for the survey of pine processionary moth, Thaumetopoea pityocampa. All the $P$. nigra stands within this network were surveyed for presence of DNB in
2009 and, for each stand with typical symptoms of DNB, samples were collected and sent for analysis to the LNPV. Finally, sample set 2 gathered samples collected in 136 stands where DNB was observed and for which the presence of Dothistroma spp. could be confirmed by the laboratory analysis. Sample sets 1 and 2 did not represent different areas because both came from all over France. However, whereas sample set 1 represented stands selected for significant DNB presence, sample set 2 mainly corresponded to stands with weak DNB impact. Disease prevalence (i.e., percent infected trees per stands) was only available for stands of sample set 2 .

For each investigated pine stand (sample sets 1 and 2), a mix of needles showing typical symptoms of DNB (red bands) were collected from several affected trees, placed into an individual tightly closed paper bag, and immediately sent for analysis. Typically, 5 to 30 needles were sampled on two to three trees, depending on the amount of disease found in the stand. For each individual sample, 5 to 10 sections, each $5 \mathrm{~mm}$ in length, of different needles bearing red bands were excised aseptically and carefully transferred into a 2-ml sterile centrifuge tube. Total DNA was extracted and analyzed by a multiplex real-time polymerase chain reaction (PCR) analysis following the protocol described by Ioos et al. (16) to determine the presence of $D$. pini or $D$. septosporum. Basically, three primer pairs were used, specific to either D. pini, D. septosporum, or $18 \mathrm{~S}$ ribosomal DNA. The $18 \mathrm{~S}$ was used as an amplification control. Three replicates were done for each of the primer pairs. A Dothistroma sp. was considered to be present only if an amplification was obtained with the relevant specific primer for at least two replicates. If no amplification was obtained with the $18 \mathrm{~S}$ amplification control for two or more replicates, the detection was considered to be not valid and no result was derived from the analysis.

TABLE 1. Herbarium specimens analyzed for presence of the two Dothistroma spp.

\begin{tabular}{|c|c|c|c|c|c|c|}
\hline Species & Specimen $^{\mathrm{a}}$ & Host & Year & Location & Coordinate & Collector \\
\hline Dothistroma pini & $260^{\mathrm{b}}$ & Pinus nigra $\mathrm{sp}$. laricio & 1965 & Les Barres (Loiret) & $\mathrm{E} 2^{\circ} 43^{\prime} 47.6^{\prime \prime} \mathrm{N} 47^{\circ} 50^{\prime} 12.8^{\prime \prime}$ & M. Arbez \\
\hline D. pini & NCY012997c & P. sylvestris & 1907 & Tourbière du Beillard (Vosges) & $\ldots$ & M. Joigny \\
\hline ND & $45^{\mathrm{b}}$ & P. sylvestris & 1969 & Garenne de Perthus (St Dizier) & $\mathrm{E} 3^{\circ} 31^{\prime} 52.6^{\prime \prime} \mathrm{N} 46^{\circ} 51^{\prime} 16^{\prime \prime}$ & M. Morelet \\
\hline ND & $1481^{\mathrm{b}}$ & P. nigra sp. salzmanii & 1962 & Amance & $\mathrm{E} 3^{\circ} 40^{\prime} 46.1^{\prime \prime} \mathrm{N} 44^{\circ} 17^{\prime} 54.8^{\prime \prime}$ & M. Morelet \\
\hline ND & NCY012993 & $P$. incinata & 1862 & Gérardmer (Vosges) & $\ldots$ & M. Godron \\
\hline ND & NCY012995 & P. pumilis & 1850 & Le Belieu (Doubs) & $\ldots$ & M. Grenier \\
\hline ND & NCY012996 & P. pumilis & 1844 & Le Belieu (Doubs) & $\ldots$ & M. Grenier \\
\hline ND & NCY012998c & P. sylvestris & 1831 & Bouxwiller (Bas-Rhin) & $\ldots$ & M. Buchinger \\
\hline ND & NCY012999c & P. nigra sp. salzmanii & 1845 & Saint Guilhem le désert & $\ldots$ & M. Touchy \\
\hline D. septosporum & $170^{\mathrm{b}}$ & P. nigra sp. laricio & 1962 & Gondreville & $\mathrm{E}^{\circ} 51^{\prime} 31.5^{\prime \prime} \mathrm{N} 46^{\circ} 44^{\prime} 31.6^{\prime \prime}$ & M. Morelet \\
\hline D. septosporum & $173^{\mathrm{b}}$ & P. nigra & 1962 & Vitrey-sur-Mance & $\mathrm{E} 4^{\circ} 56^{\prime} 43.2^{\prime \prime} \mathrm{N} 48^{\circ} 37^{\prime} 42.3^{\prime \prime}$ & M. Morelet \\
\hline D. septosporum & $266^{\mathrm{b}}$ & P. nigra sp. laricio & 1964 & Champvert & $\mathrm{E} 2^{\circ} 45^{\prime} 2.4^{\prime \prime} \mathrm{N} 43^{\circ} 28^{\prime} 58.7^{\prime \prime}$ & De Perrier \\
\hline D. septosporum & $1262^{\mathrm{b}}$ & Pinus sp. & 1964 & Haguenau & $\mathrm{E}^{\circ} 58^{\prime} 47.4^{\prime \prime} \mathrm{N} 48^{\circ} 40^{\prime} 55.6^{\prime \prime}$ & M. Morelet \\
\hline D. septosporum & $226^{\mathrm{b}}$ & P. sylvestris & 1965 & Les Barres (Loiret) & $\mathrm{E} 5^{\circ} 45^{\prime} 39.7^{\prime \prime} \mathrm{N} 47^{\circ} 48^{\prime} 51.5^{\prime \prime}$ & M. Morelet \\
\hline D. septosporum & $227^{\mathrm{b}}$ & P. sylvestris & 1965 & Dijon & $\mathrm{E} 4^{\circ} 56^{\prime} 43.2^{\prime \prime} \mathrm{N} 48^{\circ} 37^{\prime} 42.3^{\prime \prime}$ & L. Lanier \\
\hline D. septosporum & $257^{\mathrm{b}}$ & P. ponderosa & 1965 & Les Barres (Loiret) & $\mathrm{E} 5^{\circ} 2^{\prime} 29.8^{\prime \prime} \mathrm{N} 47^{\circ} 19^{\prime} 59.7^{\prime \prime}$ & - \\
\hline D. septosporum & $261^{\mathrm{b}}$ & P. sylvestris & 1965 & Puy de Dôme & $\mathrm{E} 2^{\circ} 43^{\prime} 47.6^{\prime \prime} \mathrm{N} 47^{\circ} 50^{\prime} 12.7^{\prime \prime}$ & C. Delatour \\
\hline D. septosporum & $262^{\mathrm{b}}$ & P. nigra & 1965 & Rainans & $\mathrm{E} 3^{\circ} 7^{\prime} 43.5^{\prime \prime} \mathrm{N} 45^{\circ} 42^{\prime} 56^{\prime \prime}$ & C. Delatour \\
\hline D. septosporum & $263^{b}$ & P. nigra & 1965 & Chassigny & $\mathrm{E} 5^{\circ} 28^{\prime} 39^{\prime \prime} \mathrm{N} 47^{\circ} 9^{\prime} 26.9^{\prime \prime}$ & C. Delatour \\
\hline D. septosporum & $264^{\mathrm{b}}$ & P. nigra & 1965 & Liffol le Grand & $\mathrm{E} 5^{\circ} 23^{\prime} 12.1^{\prime \prime} \mathrm{N} 47^{\circ} 43^{\prime} 8.1^{\prime \prime}$ & C. Delatour \\
\hline D. septosporum & $424^{\mathrm{b}}$ & P. sylvestris & 1966 & D64 entre Ranchal et Cours & $\mathrm{E}^{\circ} 34^{\prime} 28.3^{\prime \prime} \mathrm{N} 48^{\circ} 18^{\prime} 55.8^{\prime \prime}$ & C. Delatour \\
\hline D. septosporum & $102^{\mathrm{d}}$ & P. nigra & 1974 & $\begin{array}{l}\text { Col du Loumenot (Saint Julien } \\
\text { d'Arpaon) }\end{array}$ & $\mathrm{E} 4^{\circ} 24^{\prime} 7^{\prime \prime} \mathrm{N} 46^{\circ} 7^{\prime} 37.2^{\prime \prime}$ & A. Soutrenon \\
\hline D. septosporum & $143^{\mathrm{d}}$ & P. nigra sp. laricio & 1974 & Saint Pons & $\mathrm{E} 1^{\circ} 25^{\prime} 54.4^{\prime \prime} \mathrm{N} 44^{\circ} 51^{\prime} 14.1^{\prime \prime}$ & A. Soutrenon \\
\hline D. septosporum & $438^{d}$ & P. nigra sp. laricio & 1982 & Nadaillac de rouge & $\mathrm{E} 2^{\circ} 6^{\prime} 32.3^{\prime \prime} \mathrm{N} 45^{\circ} 18^{\prime} 45.2^{\prime \prime}$ & J. F. Abgrall \\
\hline D. septosporum & $551^{\mathrm{d}}$ & P. nigra sp. laricio & 1982 & Vitray & $\mathrm{E} 2^{\circ} 40^{\prime} 50^{\prime \prime} \mathrm{N} 46^{\circ} 36^{\prime} 54^{\prime \prime}$ & DDA Allier \\
\hline D. septosporum & $471^{\mathrm{d}}$ & P. nigra sp. laricio & 1983 & Saint-Hilaire-Foisson & $\mathrm{E} 1^{\circ} 25^{\prime} 54.4^{\prime \prime} \mathrm{N} 44^{\circ} 51^{\prime} 14.1^{\prime \prime}$ & DDA Tulle \\
\hline D. septosporum & $569^{d}$ & P. nigra sp. austriaca & 1985 & Nadaillac & $\mathrm{E} 3^{\circ} 18^{\prime} 25^{\prime \prime} \mathrm{N} 47^{\circ} 15^{\prime} 5.4^{\prime \prime}$ & DDA Lot \\
\hline D. septosporum & $586^{\mathrm{d}}$ & P. nigra sp. laricio & 1986 & $\begin{array}{l}\text { FD des Taillis de Dompierre } \\
\text { (Saint Bonnet) }\end{array}$ & $\mathrm{E}^{\circ} 33^{\prime} 38.2^{\prime \prime} \mathrm{N} 48^{\circ} 44^{\prime} 48.7^{\prime \prime}$ & ONF \\
\hline D. septosporum & $604^{\mathrm{d}}$ & P. nigra sp. austriaca & 1986 & FD Commercy & $\mathrm{E} 7^{\circ} 49^{\prime} 12.7^{\prime \prime} \mathrm{N} 48^{\circ} 50^{\prime} 9.7^{\prime \prime}$ & ONF Commercy \\
\hline D. septosporum & $455^{\mathrm{d}}$ & P. nigra sp. austriaca & 1982 & Champagnole & $\mathrm{E}^{\circ} 21^{\prime} 16.9^{\prime \prime} \mathrm{N} 48^{\circ} 43^{\prime} 53.9^{\prime \prime}$ & ONF Lons le Saulnier \\
\hline
\end{tabular}

a All specimens are samples of pine needles showing symptoms of Dothistroma needle blight.

b INRA-Nancy.

c Jardin Botanique du Montet, Nancy.

d CEMAGREF-Grenoble. 
Thirty herbarium specimens of pine needles showing symptoms of DNB were available (Table 1). The specimens came from eastern France, from the Mediterranean area to the northeastern German border. The majority of them came from natural ecosystems, mostly forests. The only exceptions were specimens from Amance (one specimen) and Les Barres (three specimens), which came from an arboretum. As for fresh samples, herbarium specimens were analyzed by real-time PCR to determine the Dothistroma sp. present at that time in each locations. For each herbarium specimen, pieces bearing conidiomata were cut from different needles with a scalpel and put into a $2-\mathrm{ml}$ sterile centrifuge tube ( 1 to 10 pieces per specimen). DNA extraction and real-time PCR analysis were done as described by Ioos et al. (16) for fresh samples, except for the specimens collected in the beginning of the 1990s. For these very old samples, some steps of DNA extraction were adapted. Specimen were frozen in nitrogen before grinding and the incubation at $65^{\circ} \mathrm{C}$ with RNase was performed for $1 \mathrm{~h}$. Furthermore, all precipitation steps were done in a freezer instead of ice, and their time of incubation was $3 \mathrm{~h}$. The identification process, from the extraction to the PCR, was repeated twice.

Analysis of Dothistroma spp. distribution in relation with climate. For each stand, the nearest meteorological station of the Météo-France network with data available over a 15 -year period (1990 to 2005) was selected. The median distance between the plot and the meteorological station was $10 \mathrm{~km}$ (range of 3 to 20 $\mathrm{km}$ ). The climatic variables tested were the means over the 1990 to 2005 period of minimum, maximum, and mean daily temperatures and sum of precipitations (in millimeters) for four periods: winter (December-February), spring (March-May), summer (June-August), and autumn (September-November). Precipitation and temperature in summer were not correlated for the set of studied stands (Spearman $r$ of $0.016, P=0.81$ ).

The relationship between the presence of $D$. pini and climate in the 216 stands with confirmed DNB was investigated by logistic regression using the Genmod procedure of SAS (SAS/STAT 8.1; SAS Institute Inc., Cary, NC). The logistic function was used as a link. The model was built by a forward selection procedure and the model quality was checked (residual distribution and influential point).

Spatial distribution of DNB impact in France. The presence of both $D$. pini and $D$. septosporum was compared with the spatial distribution of DNB severity in France. The DSF has implemented a database which stores records of health problems observed in France by a network of foresters trained for the diagnosis of all types of health affections, including abiotic, entomological, or pathological damage. These observers devoted only part of their time to DSF activities (i.e., observation and report of forest heath problems). Altogether, during 1989 to 2006, $\approx 12,800$ health problems on Pinus spp. were recorded in the database, 780 of which concerned DNB. The symptoms induced by Dothistroma spp. are characteristic and a reliable diagnostic can often be established in the field. However, for approximately a third of the DNB reports, a needle sample was taken in the affected stand and sent to the LNPV for a laboratory diagnostic. The test performed until 2007 did not enable researchers to specify which Dothistroma sp. was involved in the reported DNB case; thus, this information is not available for this data set. After 2006, a change in the data collection procedure precluded the use of the data in the same analysis. Thus, records used in the previous section to study the distribution of Dothistroma spp. are not taken into account in this analysis.

The nonsystematic and nonhomogeneous method used for data collection and the fact that only occurrence is recorded impeded the data analysis and did not allow the estimation of infected host frequency. The local number of DNB records observed strongly depends on the local density of hosts and observation intensity. Indeed, more DNB records will be produced in areas where the host (the so-called "at-risk" population) is abundant or economi- cally important, and some observers will devote more time to their DSF activity and, therefore, produce more records for a given problem intensity. An expected local number of DNB records was estimated to compare with the observed one in order to assess whether DNB was of significant local importance. The methodology used was adapted from what is done in medical epidemiology (19). Basically, the raw number of DNB records was compared with the raw number of records for a set of problems selected to be typical of the at-risk population. The local density of reference records is considered to be proportional to the at-risk population's local importance and to the observation intensity by local observers and, thus, can be used to estimate an expected local number of DNB records. As reference records, we used most health problems affecting pine trees other than DNB. However, a limited number of problems representing a very high proportion of the records, such as occurrence of T. pityocampa, were not used in order to avoid possible bias linked to heterogeneous distribution of records in time or space.

In a first step, time was not taken into account and all the records of 1989 to 2006 were pooled. To estimate the local density of DNB and reference records, a nonparametric kernel estimation method was used $(13,28)$. This method estimates the record density on each point of a grid. Each record is weighted by the kernel function according to the distance to the grid point. The bandwidth is the important kernel parameter controlling the weight decay with the distance to the grid point. The records density for each point of a 10-by-10-km grid was computed. The quartic kernel with a bandwidth of $80 \mathrm{~km}$ was used for both DNB and reference records density. The least square cross-validation (27) was used to estimate the values of the bandwidth on several portions of the surveyed area, and to choose one which was large enough to avoid cases lacking records within the discus defined by the bandwidth.

A standardized record rate (SRR) was produced by dividing the observed DNB records density by the expected DNB records density, which was computed as the product of the reference records density and the average DNB record rate for France (total number of DNB records divided by total number of reference records). To assess the quality of SRR local estimates, the potential bias (measure of the local potential departure from the mean) and the standard deviation were computed by bootstrap analyses for each grid point. New simulated data sets were automatically generated by assigning to each of the used records (DNB plus reference) a new value (either DNB or reference record) depending on the estimated local SRR. In total, 1,000 simulated data sets were generated by this method and used to produce 1,000 SRR simulated estimates. The bias was estimated by comparing the observed SRR to the averaged simulated ones. The standard deviation of the SRR was estimated from the mean squared difference between the observed SRR and the averaged simulated ones. All these analyses were done using the R statistics software.

In a second step, the annual dynamic of DNB records was computed. This was done only for five areas of France with enough reference records (Fig. 1B). The set of reference diseases used in the previous analysis was also used to standardize the raw DNB record number. The annual number of reference records in an area was computed as the sum over all DSF observers present in the area of the average annual number of reference records per observers. The annual SRR was estimated as the annual observed number of DNB records divided by the annual expected observed number of DNB records ( $N_{\text {ref }}$ multiplied by the average DNB record rate for all France).

Disease severity in location with presence or absence of $\boldsymbol{D}$. pini. To investigate the effect of the presence or absence of $D$. pini on disease severity, two different measurements of disease severity were used. First, the presence of the two Dothistroma spp. was compared with the regional DNB severity estimated from the DSF database (SRR, see above). Each location of the 

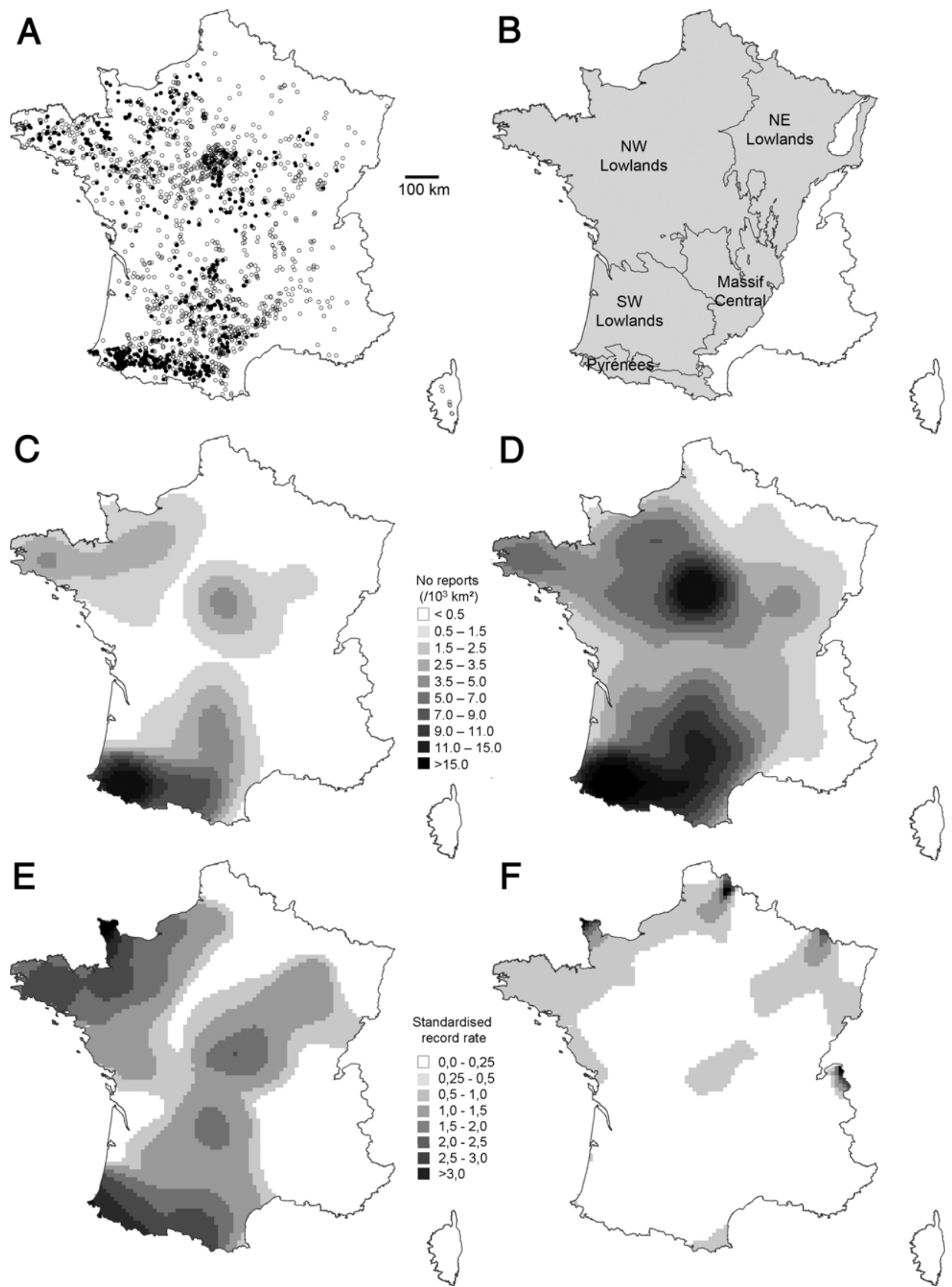

Fig. 1. Distribution of Dothistroma needle blight (DNB) in France. A, Records on laricio pine in the Département de la Santé des Forêts database $(\bullet$, DNB and 0 , others health problems used as reference); B, areas for which the annual evolution of the DNB standardized record rate was computed; C, density of DNB record; D, density of reference problems records; E, DNB standardized record rate; and F, standard deviation in the DNB standardized record rate. 
2007 to 2010 Dothistroma spp. survey was associated with the closest grid point estimate of SRR using a GIS device. The relationship between $D$. pini presence and SRR estimate was studied. Second, the disease prevalence associated with the record (i.e., the percentage of affected trees in the stand) was used as a measurement of the stand-level disease severity. This analysis was limited to the sampled stands concerning $P$. nigra subsp. laricio because there were not enough stands with other pine species to be included in the analysis. The disease prevalence at the stand level was available only for 128 P. nigra subsp. laricio stands of sample set 2 .

Differences in disease prevalence and in SRR between sites infected or not infected by $D$. pini were statistically assessed by variance analysis. Prior to analysis, the data of disease prevalence was transformed by taking the arcsin of square root. To avoid any possible climate bias on the disease severity that could have been caused by the differences of distribution areas between the two Dothistroma spp., the total rain in March to May and average temperature in June, July, and August during the 1990 to 2005 period were used as a covariate. These climate variables are known to be important for the epidemiology of the DNB $(23,31)$.

\section{RESULTS}

Dothistroma spp. distribution in France. Altogether, during the 2007 to 2010 survey, D. septosporum and D. pini were detected in 133 and 123, respectively, of the 216 studied stands. Both species co-occurred in 40 stands. Most of the samples were collected on $P$. nigra subsp. laricio, whereas only 18 samples came from other pine species: 9 on $P$. nigra subsp. austriaca, 4 on $P$. pinaster, and 5 on $P$. sylvestris. D. septosporum was found on all pine species while $D$. pini was found only on P. nigra (subsp. laricio and austriaca). D. septosporum was evenly distributed over France except in the Mediterranean area, where it was scarcely found (Fig. 2). In spite of a specific survey of DNB, this disease was never found in Corsica, which is the only place in France where $P$. nigra subsp. laricio is native. D. pini showed a more restricted distribution area, being very infrequent in the north and east of the country as well as in the mountainous areas (Massif Central and Pyrénées).

Detection and identification of a Dothistroma sp. were successfully achieved for 23 of the 30 herbarium specimens available (Table 1). Most of the positive specimens were found to be infected by D. septosporum. D. pini was only detected on two occasions: one specimen collected in 1907 from Toubière du Beillard in northeastern France and the other one collected in 1965 in the Arboretum des Barres in central France.

Analysis of Dothistroma spp. distribution in relation with climate. The distribution of $D$. pini in France was strongly related to climate variables. In particular, two variables (i.e., mean temperature during June to August and total rainfall during June to August) explained a large part of the distribution of this species (Table 2). Indeed, high mean summer temperature strongly correlated with the presence of $D$. pini because the probability of this species presence was 4.1 -fold higher for each additional $1^{\circ} \mathrm{C}$ increase in mean temperature during June-August (Fig. 3A; Table 2). This result explained the absence of this pathogen species in the north and east of France and at higher elevations, in areas with a mean summer temperature $<16$ to $17^{\circ} \mathrm{C}$ (Fig. 2). Summer rain had a minor effect on the frequency of $D$. pini presence, with an odd ratio of only 1.2 (increase in presence probability for each $10 \mathrm{~mm}$ of additional summer rain) (Table 2). The influence of summer rain explained mainly the scarcity of $D$. pini in areas with low summer precipitations in northwestern France (Fig. 3B).

Spatial distribution of DNB severity in France. The ratio of records number/forest surface area was significantly higher for $P$.

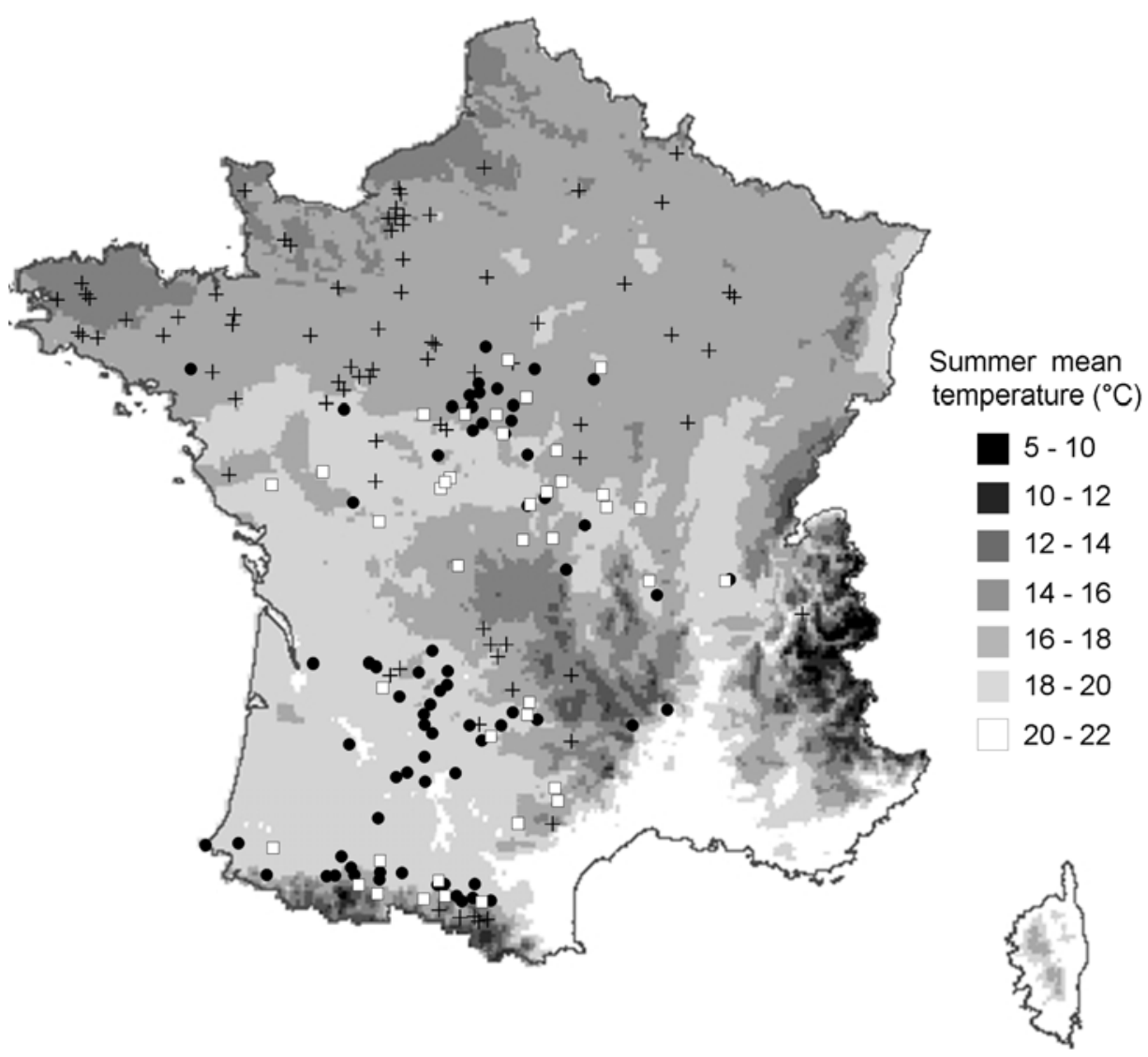

Fig. 2. Presence of the two Dothistroma spp. in the 2007 to 2010 survey (+, D. septosporum; $\bullet$, D. pini; and $\square$, both species). Mean summer temperature, June to August (source: Aurelhy, Météo-France, 1960 to 1990). 
nigra subsp. laricio than for other pine species. Indeed, during 1989 to 2006, 6.67 cases were recorded per $10^{3}$ ha of P. nigra subsp. laricio forest compared with $0.00,0.02,0.07,0.01$, and 0.01 per $10^{3}$ ha of forest of $P$. halepensis, $P$. uncinata, $P$. nigra subsp. austriaca, $P$. pinaster, and $P$. sylvestris respectively (based on forest surface data for France provided by the Inventaire Forestier National). P. nigra subsp. laricio represented $94 \%$ of the available DNB records in the database; therefore, only records concerning that species were considered in the at-risk population (i.e., a total of 687 DNB records and 2,003 reference records) (Fig. 1A).

DNB records were notably frequent in western and central France and in the Pyrenean piedmont (Fig. 1C). A very limited number of DNB case were recorded for northeastern France, whereas none was registered for the Mediterranean area. In particular, no DNB case was recorded for Corsica, where this pine species is indigenous and represents an important proportion of the forest surface. The distribution of the reference records was slightly different compared with DNB records, with a very high frequency in the Pyrenean piedmont and in central France (Fig. 1D). A low SRR standard deviation (of 0.1 to 0.3 ) was observed throughout most of the country (Fig. 1F). However, in some limited areas, in particular in the Cotentin (northwestern France), the SRR standard deviation exceeded 2, which means that the SRR values for these locations should be interpreted with care. The bias in the SRR remained also low over most of the country $(<0.2)$, with areas of high value in the same area as high value of SRR standard deviation (result not shown). Thus, the SRR could be safely interpreted for a major part of France, except part of the

TABLE 2. Relationship between climate and Dothistroma pini presence: results of the logistic regression analysis ${ }^{\mathrm{a}}$

\begin{tabular}{lccc}
\hline Parameter $^{\mathrm{b}}$ & df & $\begin{array}{c}\text { Odd ratio } \\
\text { (confidence interval) }^{\mathrm{c}}\end{array}$ & $\begin{array}{c}\text { Wald } \chi^{2} \\
(P \text { value })\end{array}$ \\
\hline Mean temperature & 1 & $4.1(2.8-6.1)$ & $48.8(<0.0001)$ \\
Rain & 1 & $1.2(1.1-1.4)$ & $14.0(<0.0001)$ \\
\hline
\end{tabular}

${ }^{a}$ Model deviance was 193.8 for $213 \mathrm{df}$.

${ }^{\mathrm{b}}$ In June to August.

${ }^{\text {c }}$ Measure the increase in the probability of $D$. pini presence per unit summer temperature (for each $1^{\circ} \mathrm{C}$ ) and rainfall (for each $10 \mathrm{~mm}$ ) increase, i.e., probability of $D$. pini presence $4.1 \times$ higher for each additional $1{ }^{\circ} \mathrm{C}$ increase.

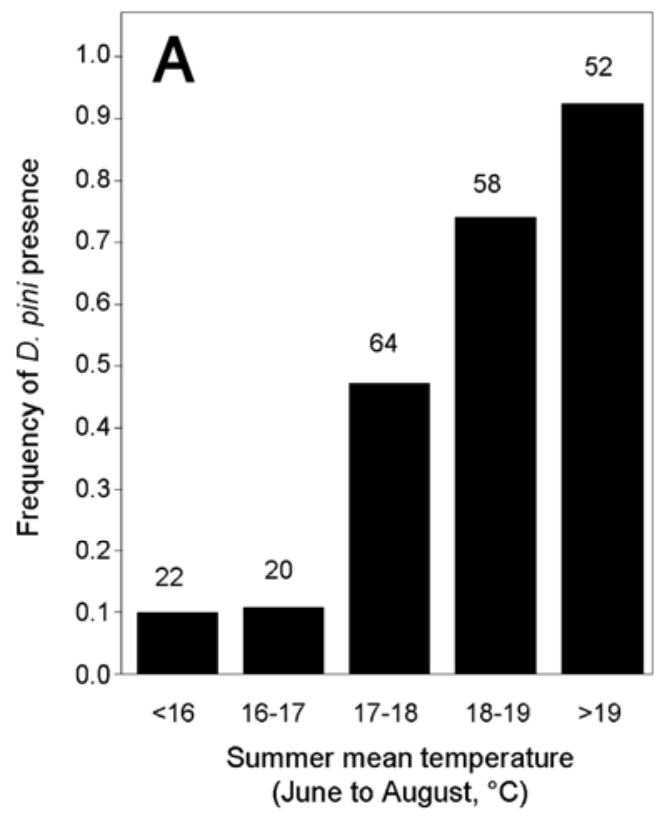

Cotentin, close to the Channel. The SRR was high in western France and in the Pyrenean piedmont and, to a lesser degree, in central France, and notably low in eastern France.

Overall, a continuous increase of DNB SRR could be observed in France since 1992 (Fig. 4). A very limited number of DNB cases were recorded before 1992 and they remained scarce until 1998, when a dramatic increase in the SRR could be observed. The disease outbreak was observed first in southwestern France (Pyrenean piedmont and southwestern lowland) and later in northern France, in particular in the northwestern lowland (in 2001 to 2002). Since 1998, the disease has been consistently reported in the western half of France.

Comparison of disease severity versus presence of $D$. pini. The distribution of $D$. pini within France was compared with the distribution of DNB (Figs. 1E and 2); no obvious relation was observed between areas of high disease record and the pattern of spatial distribution area of $D$. pini. For example, DNB SRR was equally high in the Pyrenean piedmont, where $D$. pini was domi-

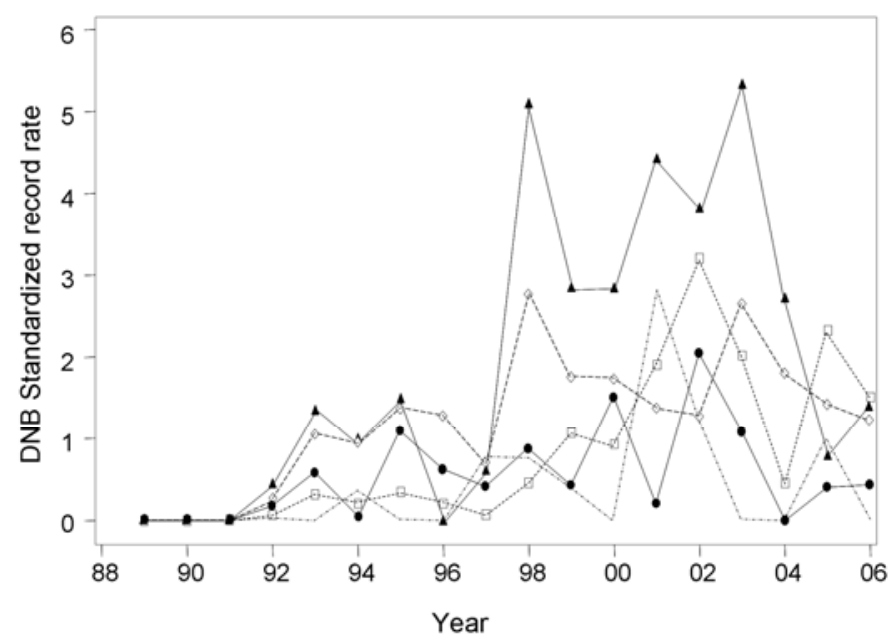

Fig. 4. Annual evolution of Dothistroma needle blight (DNB) in the Département de la Santé des Forêts database. Pyrénées (\), southwestern lowland $(\diamond)$, northwestern lowland $(\square)$, Massif Central $(\bullet)$, and northwestern lowland (---). Annual standardized record rate in a given area represents the ratio between observed and expected DNB record numbers.

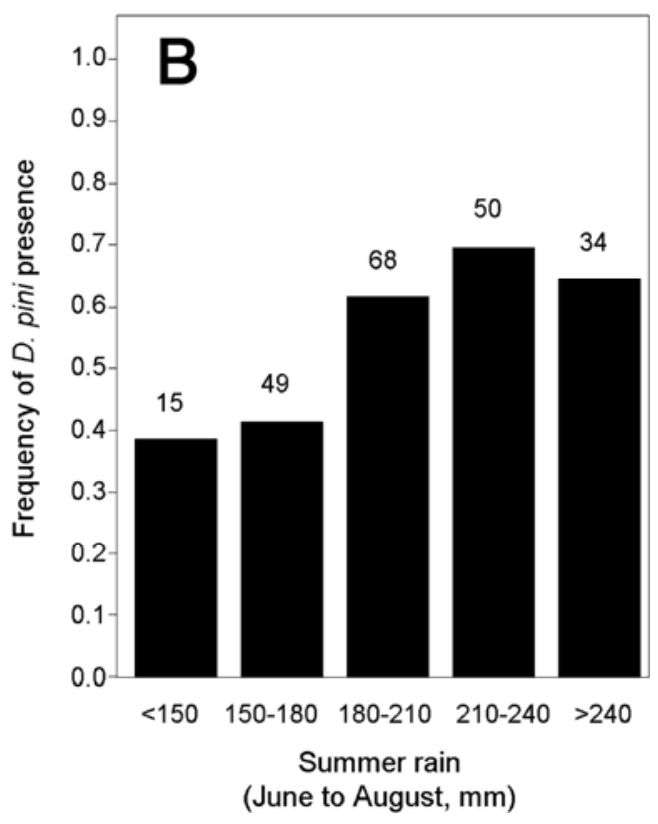

Fig. 3. Frequency of Dothistroma pini in needle blight affected pine stands during the 2008 to 2010 survey according to A, mean summer temperature (JuneAugust) and B, mean summer rain (June to August). 
nant, and in northern France, close to the Channel, where only $D$. septosporum was found. Indeed, no significant relation was found between $D$. pini presence and needle blight SRR (Table 3). The mean SRR rate was $1.00 \pm 0.09$ when $D$. pini was absent and $1.01 \pm 0.09$ when it was present. By contrast, the DNB SRR was significantly correlated to climate variables and, in particular, to rainfall in the June to August period, with a disease record rate positively affected by increasing rainfall.

As for the DNB SRR, no significant relationship was observed between the presence of $D$. pini and the stand level disease prevalence (Table 4). The mean prevalence values in stands with or without $D$. pini were $45.3 \pm 6.5$ and $48.8 \pm 8.9 \%$, respectively. Mean DNB prevalence in stands also significantly increased with rainfall and mean temperature in June to August.

\section{DISCUSSION}

This work demonstrated that $D$. pini, previously thought to be absent from Western Europe and reported for the first time in France by Ioos et al. (15), is actually widespread in the southern part of the country, where this species was present in the majority of the sites affected by DNB. D. pini was detected in old herbarium specimens collected in France. Although it is still not possible to determine precisely when this pathogen arrived in Western Europe, our results suggest that the emergence of DNB in France in the early 1990s was not caused by a recent introduction of this species. Indeed, there was no obvious relationship between the spatial patterns of disease severity and the presence of D. pini.

In this study, the presence of $D$. pini could be demonstrated in herbarium specimens collected back to 1907 and 1965, which suggests that this species is not a recent invader in France. However, D. pini was detected from only two herbarium specimens. Moreover, for the specimen of 1907 from the Tourbière du Beillard, the sample was too small to repeat the detection procedure. Thus, this result should be taken with caution.

The origin of D. septosporum has been controversial, with a proposed center of origin in Central America or the Himalayas $(11,16)$. Morelet $(20)$ proposed that this species had been present in France since the end of the 19th century. Indeed, a fungus morphologically very similar to $D$. septosporum was described by Vuillemin (26) in 1896 on P. nigra and P. sylvestris in northeastern France under the name Hypostonum flichianum. Unfortunately, the herbarium of Vuillemin has not been kept and, thus, it cannot be confirmed that this description referred to either $D$. septosporum or D. pini. However, the identification of a Dothistroma sp. from a specimen collected in northeastern France in 1907 confirms that DNB has been present in France for at least a century and makes the exotic nature of these two species in Europe questionable.

It is worth noticing that DNB could not be found in Corsica, although the very susceptible P. nigra subsp. laricio is abundant in the local forest where it is native, in contrast to continental France, where it is introduced. This is surprising because it may

TABLE 3. Relationship between Dothistroma pini presence and Dothistroma needle blight standardized record rate in the Département de la Santé des Forêts database ${ }^{\mathrm{a}}$

\begin{tabular}{lrrrc}
\hline Source & Sum & & \\
\hline Model & df & square & $F$ & $P>F$ \\
Error & 3 & 8.81 & 10.45 & $<0.0001$ \\
Presence of $D$. pini & 212 & 56.86 & $\ldots$ & $\ldots$ \\
Rain (June-August) & 1 & 0.01 & 0.00 & 0.961 \\
Mean temperature (June-August) & 1 & 6.14 & 22.89 & $<0.0001$ \\
\hline
\end{tabular}

a Standardized record rate available for the 216 stands surveyed in 2007 to 2010 . not be explained by unfavorable climatic condition because, in Corsica, Laricio pine stands are mostly located in mountain areas where the climate, with wet and warm springs, should be suitable for the disease. Thus, we could not find support for the hypothesis that one of the Dothistroma sp. is native to Corsica, being present on the native host without inducing significant damages.

It may be hypothesized that $D$. pini was not frequent in France during the last century, because it was detected in only $9 \%$ of the Dothistroma sp.-positive herbarium specimens, whereas this species was detected in $57 \%$ of the stands studied during the 2007 to 2010 survey. However, many of the herbarium specimens came from areas where only D. septosporum can be found presently: only 7 of the 17 herbarium specimens from the 1960s and 1970s came from areas were $D$. pini can now be found. $D$. pini was detected from one of those seven specimens, and was collected in the Arboretum des Barres (Loiret), an area where D. pini is now common. Alternatively, the frequency of $D$. pini might have strongly increased in France. This could be related to the recent climate warming, because this species is restricted to areas with warmer summers.

The pattern of emergence indicates a spread of the disease from the southwest of France up to northern areas. This could fit with a significant role in the disease emergence of a species that requires hotter condition such as D. pini. However, no relationship could be found between the spatial pattern of DNB reported by the DSF and the distribution of $D$. pini in France. Thus far, the distribution of $D$. pini remains mainly restricted to southern regions and $D$. septosporum is the only species present in severely affected areas close to the Channel. This is in agreement with the fact that DNB also emerged recently in Great Britain, where only D. septosporum has been reported hitherto (7). The clear pattern of disease emergence, first in the south of the country with a later extension to northern areas, could also be explained if climate change was an important factor in the disease emergence. In that case, climatic conditions would have been expected to be favorable earlier in the warmer, southwestern part of France. Indeed, this study showed that disease prevalence at the stand level during the 1997 to 2010 survey was positively related to mean summer temperature. It has been reported that $\mathrm{DNB}$ requires periods of temperature of 15 to $20^{\circ} \mathrm{C}$ under continuous moisture to be severe $(12,23)$. An increased frequency of such warm and wet periods during the vegetation season has been associated with the emergence of DNB in British Columbia (31). The decade of 1990 to 2000 has been exceptionally warm in France, with normal favorable rainfall, and this could likely explain the emergence of DNB.

Temperature was the most important climatic factor to explain D. pini presence while it was less important for DNB severity. It is not unusual that temperature is the prominent factor in the climatic envelop of an organism (to explain its presence), while precipitation gets more important for explaining its local abundance (9). Also, for severity, we do not know the respective importance of $D$. pini and $D$. septosporum as causes of the symptoms, and high temperature is mostly important for $D$. pini.

Invasion of plant-pathogenic fungi closely related to indigenous species can strongly cloud the causes of disease emergence. An example of that is the Chalara sp.-induced ash decline in Europe.

TABLE 4. Relationship between Dothistroma pini presence and disease prevalence in the 128 Pinus nigra subsp. laricio stands of 2007 to 2010 (sample set 2) with prevalence data

\begin{tabular}{lrrrr}
\hline Source & df & $\begin{array}{c}\text { Sum } \\
\text { square }\end{array}$ & \multicolumn{1}{c}{$F$} & $P>F$ \\
\hline Model & 3 & 4.33 & 17.76 & $<0.0001$ \\
Error & 24 & 23.05 & $\ldots$ & $\ldots$ \\
Presence of D. pini & 1 & 0.28 & 1.49 & 0.224 \\
Rain (June-August) & 1 & 1.06 & 5.71 & 0.018 \\
Mean temperature (June-August) & 1 & 2.45 & 13.19 & $<0.001$ \\
\hline
\end{tabular}


This disease is induced by Hymenoscyphus pseudoalbidus, a species closely related to an indigenous European species, $H$. albidus (24). No quarantine regulations were originally taken against $H$. pseudoalbidus because of confusion between the two species (17). This study showed that the use of past herbarium specimens and the comparison of species distribution with the disease spatial pattern were powerful means to sort out the relation between D. pini and DNB emergence in France. However, this points out a lack of knowledge about plant-pathogenic species communities even in well-studied areas such as Europe. This is especially the case for pathogens that do not cause significant damage, as for Dothistroma spp. in France in the past. A larger use of the recently developed molecular techniques such as mass sequencing of taxonomically relevant genes in environmental samples (8) would be a significant improvement. Indeed, because these techniques are not narrowed to a list of specific organisms, a more comprehensive description of plant pathogen communities will probably be available in the near future.

\section{ACKNOWLEDGMENTS}

This work was founded by the European Union ForestFocus program. We thank all the observers of the Département de la Santé des Forêts for the report of DNB and for providing the needles samples; C. Rinaldi, from the Laboratoire National de la Protection des Végétaux (ANSES), for her technical contribution; and M. Morelet for advice that was of great help for the manuscript redaction.

\section{LITERATURE CITED}

1. Anderson, P. K., Cunningham, A. A., Patel, N. G., Morales, F. J., Epstein, P. R., and Daszak, P. 2004. Emerging infectious diseases of plants: pathogen pollution, climate change and agrotechnology drivers. Trends Ecol. Evol. 19:535-544.

2. Antonovics, J., Hood, M. E., Thrall, P. H., Abrams, J. Y., and Duthie, G. M. 2003. Herbarium studies on the distribution of anther-smut fungus (Microbotryum violaceum) and Silene species (Caryophyllaceae) in the Eastern United States. Am. J. Bot. 90:1522-1531.

3. Aumonier, T. 2002. La Maladie des Bandes Rouges Toujours en Augmentation en 2001 [Dothistroma Needle Blight (Dothistroma septosporum) still on the increase in 2001]. Pages 58-60 in: Les Cahiers du DSF, 1-2002 (La Santé des Forêts [France] en 2000 et 2001). Min. Agri. Alim. Pêche Aff. rur. (DERF), Paris.

4. Barnes, I., Crous, P. W., Wingfield, B. D., and Wingfied, M. J. 2004. Multigene phylogenies reveal that red band needle blight of Pinus is caused by two distinct species of Dothistroma, D. septosporum and D. pini. Stud. Mycol. 50:551-565.

5. Barnes, I., Kirisits, T., Akulov, A., Chhetri, D. B., Wingfield, B. D., Bulgakov, T. S., and Wingfield, M. J. 2008. New host and country records of the Dothistroma needle blight pathogens from Europe and Asia. For. Pathol. 38:178-195.

6. Barnes, I., Kirisits, T., Wingfield, M. J., and Wingfield B. D. 2011. Needle blight of pine caused by two species of Dothistroma in Hungary. For. Pathol. Online publication. doi:10.1111/j.1439-329.2010.00689.x.

7. Brown, A., and Webber, J. 2008. Red band needle blight of conifers in Britain. Research Note-Forestry Commission, No. 002.

8. Buée, M., Reich, M., Murat, C., Morin, E., Nilsson, R. H., Uroz, S., and Martin, F. 2009. 454 Pyrosequencing analyses of forest soils reveal an unexpectedly high fungal diversity. New Phytol. 184:449-456.

9. Desprez-Loustau, M. L., Robin, C., Reynaud, G., Dequé, M., Badeau, V., Piou, D., Husson, C., and Marçais, B. 2007. Simulating the effects of a climate-change scenario on the geographical range and activity of forestpathogenic fungi. Can. J. Plant Pathol. 29:101-120.

10. de Wet, J., Burgess, T., Slippers, B., Preisig, O., Wingfield, B. D., and Wingfield, M. J. 2003. Multiple gene genealogies and microsatellite markers reflect relationships between morphotypes of Sphaeropsis sapinea and distinguish a new species of Diplodia. Mycol. Res. 107:557-566.

11. Evans, H. C. 1984. The genus Mycosphaererella and its anamorphs Cercoseptoria, Dothistroma and Lecanosticta on Pines. CMI Mycological Paper 153. Commonwealth Agricultural Bureaux, Surrey, UK.

12. Gadgil, P. D. 1974. Effect of leaf temperature and leaf wetness on infection of Pinus radiata by Dothistroma pini. N. Z. J. For. Sci. 4:495-501.

13. Gatrell, A. C., Bailey, T. C., Diggle, P. J., and Rowlingson, B. S. 1996. Spatial point pattern analysis and its application in geographical epidemiology. Trans. Inst. Br. Geogr. 21:256-274.

14. Harvell, C. D., Mitchell, C. E., Ward, J. R., Altizer, S., Dobson, A. P., Ostfeld, R. S., and Samuel, M. D. 2002. Climate warming and disease risks for terrestrial and marine biota. Science 296:2158-2162.

15. Ioos, R., Fabre, B., Saurat, C., Fourrier, C., Frey, P., and Marçais, B. 2010. Development, comparison, and validation of real-time and conventional PCR tools for the detection of the fungal pathogens causing brown spot and red band needle blights of pine. Phytopathology 100:105-114.

16. Ivory, M. H. 1994. Records of foliage pathogens on Pinus species in tropical countries. Plant Pathol. 43:511-518.

17. Kowalski, T., and Holdenrieder, O. 2009. The teleomorph of Chalara fraxinea, the causal agent of ash dieback. For. Pathol. 39:304-308.

18. Lanier, L., Joly, P., Bondoux, P., and Bellemère, A. 1976. Pathologie des essences résineuses. Pages 217-232 in: Mycologie et Pathologie forestières, II Pathologie forestière, Masson, Paris.

19. Lawson, A. B. 2006. Statistical methods in spatial epidemiology. In: Wiley Series in Probability and Statistics, 2nd ed. Wiley.

20. Morelet, M. 1980. La maladie à Brunchorstia II repartition en France. Eur. J. For. Pathol. 10:354-359.

21. Mougou, A., Dutech, C., and Desprez-Loustau, M. L. 2008. New insights into the identity and origin of the causal agent of oak powdery mildew in Europe. For. Pathol. 38:275-287.

22. Mougou-Hamdane, A., Giresse, X., Dutech, C., and Desprez-Loustau, M. L. 2010. Spatial distribution of lineages of oak powdery mildew fungi in France, using quick molecular detection methods. Ann. For. Sci. Online publication. doi: $10.1051 /$ forest $/ 2009105$.

23. Peterson, G. W. 1973. Infection of Austrian and ponderosa pines by Dothistroma pini in eastern Nebraska. Phytopathology 62:1060-1063.

24. Queloz, V., Grünig, C. R., Berndt, R., Kowalski, T., Sieber, T. N., and Holdenrieder, O. 2010. Cryptic speciation in Hymenoscyphus albidus. For. Pathol. Online publication. doi:10.1111/j.1439-0329.2.

25. Shaw, M. W., Bearchell, S. J., Fitt, B. D. L., and Fraaije, B. A. 2008. Long-term relationships between environment and abundance in wheat of Phaeosphaeria nodorum and Mycosphaerella graminicola. New Phytol. 177:229-238.

26. Vuillemin, P. 1897. Les Hypostomacées, nouvelle famille de champignons parasites. Pages 15-67 in: Bull. Soc. Sci. Nancy, série II, tome XIV, fascicule XXXI, 29 ième année, 1896.

27. Wand, M. P., and Jones, M. C. 1993. Comparison of smoothing parameterizations in bivariate kernel density estimation. J. Am. Stat. Assoc. 88:520-528.

28. Wand, M. P., and Jones, M. C. 1995. Kernel Smoothing. Monographs on Statistics and Applied Probability. Chapman and Hall.

29. Watt, M. S., Kriticos, D. J., Alcaraz, S., Brown, A. V., and Leriche, A. 2009. The hosts and potential geographic range of Dothistroma needle blight. For. Ecol. Manage. 257:1505-1519.

30. Welsh, C., Lewis, K., and Woods, A. J. 2009. The outbreak history of Dothistroma needle blight: An emerging forest disease in northwestern British Columbia. Can. J. For. Res. 39:2505-2519.

31. Woods, A. J., Coates, K. D., and Hamann, A. 2005. Is an unprecedented Dothistroma needle blight epidemic related to climate change? BioScience 55:761-769. 